J. Clin. Chem. Clin. Biochem.

Vol. 20, 1982, pp. 817-824

\title{
A New Concept for Quality Control of Clinical Laboratory Investigations in the Light of Clinical Requirements and Based on Reference Method Values
}

\author{
By D. Stamm, Munich
}

(Received June 29/July 21, 1982)

Summary: Quality control is an essential element in clinical laboratory investigations. In the basic programs for quality control used in recent years accuracy control has been carried out through a comparison with methoddependent assigned values. With this system the "accuracy" of results from different laboratories is relative, and comparability is assured only when the laboratories use the same analytical method. Considering the steadily increasing variety of methods and equipment, a meaningful exchange of information in patient care, teaching and research is becoming more and more difficult; but clinical requirements make such an exchange essential.

In this paper a new concept for quality control is presented for discussion. In the basic program incorporating the new concept the method-dependent assigned values are replaced by reference method values, which are methodindependent. In addition to accuracy control, an ongoing monitoring procedure using a Shewhart control chart is also carried out. The maximum allowable day-to-day imprecision and the maximum allowable deviation from the reference method value are fixed on the basis of clinical requirements. This means that the ratio of biological variation to analytical between-day imprecision should be $\geqq 2$. If the biological variation is unknown, then the reference interval is used in its place; the quotient, reference interval/analytical between-day imprecision, should then be $\geqq 8$.

The decision limits for the interlaboratory surveys should be fixed in an analogous manner independent of the analytical method.

After the introduction of quality control based on the new concept the results from different laboratories would be comparable to the extent dictated by clinical requirements.

The main principles underlying the new concept and the effects of using the new approach are presented for discussion, and the reader is invited to submit comments in writing.

\section{Neues Konzëpt für die Qualitätssicherung klinïsch-chemischer Befunde aufgrund der ärztlichen Erfordernisse basierend auf Referenzmethoden-Werten}

Zusammenfâssung: Die Qualitätskontrolle ist ein unerläßlicher Bestandteil der klinisch-chemischen Untersuchungen. Bei den in den vergangènen Jahren benutzten Basisprogrammen für Qualitätskontrolle erfolgt die Richtigkeitskontrolle durch den Vergleich mit methodenabhängigen Sollwerten. Dadurch ist die „Richtigkeit“ der Ergebnisse aus verschiedenen Laboratorien relativiert und die Vergleichbarkeit nur bei denjenigen Laboratorien gewährleistet, die dieselbe Analysenmethode benutzen. Bei der ständig zunehmenden Vielfalt von Methoden und Geräten ist dies ein schwerwiegendes Hindernis für den Informationsaustaussch bei der Krankenbehandlung, der Forschung und der Lehre; dies widerspricht den medizinis

In der vorliegeñden Arbeit wird ein neues Konzept für die Qualitätskontrolle zur Diskussion gestellt. In dem Basisprogramm nach dem neuen Konzept treten an die Stelle der methodenabhängigen Sollwerte die methodenunabhängigen Referenzmethoden-Werte. Neben dieser Richtigkeitskontrolle wird eine ständige Kontrolle mit einer Shewhart-ǨKontrollkarte durchgeführtr. Die maximal zulässige Analysenstreuung von Tag zu Tag und die maximal zulässige Abweichung vom Referēnżmethoden-Wert werden ąufgrund der medizinischen Erfordernisse festgelegt. Danach soll der Quotient Biologische Streuung/Analysenstreuung von Tag zu Tag $\geqq 2$ sein. Falls die biologische Streuung nicht bekannt ist, wird an deren Stelle das Referenžintervall benutzt; der Quotient Referenzintervall/ Analysenstreuung von Tag zu Tag soll $\geqq 8$ sein.

Die Bewertungsgrenzen für die Ringversuche werden nach analogen Uberlegungen unabhängig von der Analysenmethode festgelegt.

Nach der Einfüuhrung der Qualitätskontrolle nach dem neuen Konzept wären die Ergebnisse aus verschiedenen Laboratorien dann im Rahmen der medizinischen Erfordernisse vergleichbar. Die wesentlichen Grundlagen des neuen Konzeptes und seine Auswirkungen werden zur Diskussion gestellt und die Leser zu schriftlichen Stellungnahmen eingeladen. 


\section{Introduction}

The necessity for quality control of clinical laboratory investigations is taken for granted these days. A great deal has been accomplished in the past $(1-6)$, but much is still left to be done. There is general dissatisfaction with the current situation (7). The purpose of this paper is not to present a new approach in a neat package, but rather to stimulate a discussion, with the goal of clarifying what is necessary in the future and on what points a consensus can be reached.

The profusion of problems cannot and should not be discussed and worked on at the national level. The discussion should not be limited by the boundaries of countries, of traditions or of current national legislation. In the course of the discussion it should also become evident where there are different approaches and different needs.

As a basis for the discussion I have formulated a number of statements. They deal with:

1. Basic principles of reliability control within the framework of clinical laboratory investigations.

2. Parameters for describing reliability.

3. Suggestions about how to measure these parameters.

4. Tolerance limits for the parameters for different medical questions.

In the following statements the goal of quality control and the framework in which quality control occurs, i.e. the clinical laboratory investigation and the various steps it encompasses, are also outlined. In formulating the statements I have limited myself to quantitative analytical results that are based on continuous scales. Other scales sometimes require different procedures.

In order that we can also establish what views we all have in common, these statements include many points that in my opinion are not controversial and thus not the subject of dispute.

\section{Statements for Discussion}

1. The goal of clinical laboratory investigations has always been to obtain reliable findings.

2. A prerequisite for reliable findings is reliable analytical results.

3. After an analytical method has been developed, the reliability criteria $(1,2)$ for this method must be evaluated and then given in detail along with the method of evaluation when the method is published (tab. 1). Reliability criteria are defined, procedures for evaluating the reliability of methods are described $(1,12)$. Reliability criteria have provided valuable information regarding the use of particular methods in clinical laboratory investigations.
4. A prerequisite for the evaluation and comparison of routine methods is the existence of reference . . methods $(8,11)$. There are three classes of reference methods. The methods in Class A and Class B require reference materials for calibration (calibration materials) (tab. 2).

5. It is well known that reference methods are unsuitable for routine investigations. For the latter routine methods must be developed. Routine methods may make use of the same analytical principle as reference methods.

6. In the past it has become clear that it is not sufficient to evaluate the reliability of a routine method only at the time the method is first developed and

Tab. 1. Reliability criteria (fròm Stämm (11)).

\begin{tabular}{ll}
\hline Criterion & Definition \\
\hline $\begin{array}{l}\text { Precision } \\
(1,8)\end{array}$ & $\begin{array}{l}\text { Agreement between replicate measurements. } \\
\text { It has no numerical value. }\end{array}$ \\
$\begin{array}{l}\text { Imprecision } \\
(1,8)\end{array}$ & $\begin{array}{l}\text { Standard deviation or coefficient of variation } \\
\text { of the results in a set of replicate measure- } \\
\text { mentis. The mean and number of replicates } \\
\text { must be stated, and the design (within-day, } \\
\text { between-day, between-laboratory) described. }\end{array}$
\end{tabular}

Accuracy Agreement between the best estimate of a $(1,8) \quad$ quantity and its "true value." It has no numerical value.

Inaccuracy Numerical difference between the mean of a set $(1,8) \quad$ of replicate measurements and the "true value." This difference (positive or negative) may be expressed in the units in which the quantity is measured or as a percentage of the "true value."

Specificity The ability of an analytical method to deter$(8,9)$ mine solely the component(s) it purports to measure.

Detection limit Analytical result which is clearly detectable $(8,10) \quad$ and different from the background noise; defined as three standard deviations of the appropriate blank value.

Tab. 2. Hierarchy of analytical methods and analytical results.

\begin{tabular}{|c|c|c|}
\hline \multicolumn{2}{|l|}{ Method } & Result \\
\hline \multicolumn{2}{|l|}{-} & "true value" \\
\hline \multicolumn{2}{|c|}{ Definitive method } & definitive value \\
\hline \multicolumn{2}{|c|}{ Reference method } & reference metho \\
\hline Class A: & tested with definitive method & \\
\hline Class B: & $\begin{array}{l}\text { not tested with definitive method, } \\
\text { but highly purified, defined } \\
\text { standard available, reliability of } \\
\text { method assured }\end{array}$ & \\
\hline Class C: & $\begin{array}{l}\text { no homogeneous standards of known } \\
\text { composition available, testing with } \\
\text { definitive method not possible }\end{array}$ & 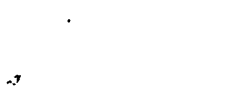 \\
\hline \multicolumn{2}{|c|}{ Routine method } & assigned value \\
\hline Class A: & $\begin{array}{l}\text { systematic error known (selected } \\
\text { method = ausgewählte Methode) }\end{array}$ & \\
\hline Class B: & systematic error not known & . \\
\hline
\end{tabular}


published. Rather, it is also necessary to evaluate some of the reliability criteria when the method is introduced in to a laboratory, and other criteria must even be subject to an ongoing monitoring process, i.e. quality control. The objectives of quality control are summarized in table 3.

7. In the Federal Republic of Germany there is a basic program for quality control that has proven effective (tab. 4). Control specimens are used in this basic program $(11,13,14)$.

Tab. 3. Requirements to be met by an optimal quality control system (modified from Büttner (1967), Z. Klin. Chem. Klin. Biochem. 5, 44).

1. Monitoring of random errors $=$ precision control.

2. Monitoring of systematic errors = accuracy control.

3. Monitoring of the effects of the matrix on precision, accuracy and specificity.

4. Monitoring of trends.

5. Monitoring over the whole clinically relevant range of concentrations.

6. Ongoing applicability.

7. Deviations immediately recognizable.

8. Applicability with mechanized analytical systems.

9. Time and expense within acceptable limits.

10. Applicability of the basic program from laboratory at physician's office to central laboratory.

11. Specially trained staff not required.

Tab. 4. Basic program according to the Guidelines of the Medical Society of West Germany.

1. Internal quality control

a) Precision control

at the most frequent decision limit, by analyzing samples of the same control specimen in every run of analyses.

b) Control of accuracy

over the whole clinically relevant range of measurement, by analyžing an accuracy control specimen in every 4th run of analyses, the control specimen being selected from a number of different control specimens kept on hand.

2. External quality control

in the form of short-term interlaboratory surveys, with at least two control specimens having different concentrations.

\section{Accuracy control as part of internal quality control} and in interlaboratory surveys is"based on assigned values that are method:dependent. The assigned values are determined in high-quality laboratories that are referred to as reference laboratories (15). As is generally known, the differences between assigned values obtained with different methods can be so large that this affects the clinical use of the results (tab. 5).

9. The explanation for these differences (11) can be found in the fact that the analytical results contain different components (tab. 6).
Tab. 5. Assigned values for creatinine - Reg. No. 28300 .

\begin{tabular}{lll}
\hline Component & Method of analysis & $\begin{array}{l}\text { Assigned } \\
\text { value }\end{array}$ \\
\hline $\begin{array}{l}\text { Creatinine } \\
(\mathrm{mg} / \mathrm{dl}) .\end{array}$ & $\begin{array}{l}\text { Jaffé reaction after adsorption } \\
\text { on fuller's earth, with deproteini- } \\
\text { zation }\end{array}$ & 1.23 \\
& $\begin{array}{l}\text { Enzymatic } \\
\text { Jaffé reaction, deproteinization } \\
\text { with trichloroacetic acid }\end{array}$ & 1.15 \\
& $\begin{array}{l}\text { Jaffé reaction, deproteinization } \\
\text { with picric acid }\end{array}$ & 1.8 \\
& $\begin{array}{l}\text { Jaffé reaction, without deproteini- } \\
\text { zation, kinetic } \\
\text { Jaffé reaction, AutoAnalyzer }{ }^{\circledR} \mathrm{I},\end{array}$ & 1.65 \\
& $\begin{array}{l}\text { II, SMA } \\
\text { Jaffé reaction, without depro- } \\
\text { teinization, with phosphate buffer, } \\
\text { kinetic }\end{array}$ & 1.45 \\
\hline
\end{tabular}

Tab. 6. Components of analytical results.

\begin{tabular}{|c|c|c|c|c|c|c|}
\hline \multirow{2}{*}{$\begin{array}{l}\text { Solutions } \\
\text { (Index) }\end{array}$} & \multirow{2}{*}{$\begin{array}{l}\text { Read- } \\
\text { ing } \\
\text { (A) }\end{array}$} & \multicolumn{2}{|c|}{ Components } & \multirow[b]{2}{*}{$\begin{array}{l}\text { Non- } \\
\text { speci- } \\
\text { fic } \\
\text { com- } \\
\text { ponent } \\
\text { (N) }\end{array}$} & \multirow[b]{2}{*}{$\begin{array}{l}\text { Inter- } \\
\text { fer- } \\
\text { ence } \\
\text { com- } \\
\text { pon- } \\
\text { ent } \\
\text { (I) }\end{array}$} & \multirow[b]{2}{*}{$\begin{array}{l}\text { Result, } \\
\text { e.g. } \\
\text { con- } \\
\text { centra- } \\
\text { tion }\end{array}$} \\
\hline & & $\begin{array}{l}\text { Best } \\
\text { esti- } \\
\text { mate } \\
\text { of } \\
\text { "true } \\
\text { value" } \\
\text { (T) }\end{array}$ & $\begin{array}{l}\text { Defi- } \\
\text { ciencies } \\
\text { in pro- } \\
\text { cedure }\end{array}$ & & & \\
\hline $\begin{array}{l}\text { Primary } \\
\text { standard } \\
\text { solution (S) }\end{array}$ & As & $c_{\mathrm{TS}}$ & $\pm c_{\mathrm{DS}}$ & & & $=c_{\mathrm{S}}$ \\
\hline $\begin{array}{l}\text { Control } \\
\text { specimen (C) }\end{array}$ & $\mathbf{A}_{\mathbf{C}}$ & $c_{\mathrm{TC}}$ & $\pm c_{\mathrm{DC}}$ & $\pm c_{\mathrm{NC}}$ & & $=c_{\mathrm{C}}$ \\
\hline $\begin{array}{l}\text { Patient } \\
\text { specimen }(P)\end{array}$ & $\mathbf{A P}_{\mathbf{P}}$ & $c_{\mathrm{TP}}$ & $\pm c_{\mathrm{DP}}$ & $\pm c_{\mathrm{NP}}$ & $\pm c_{\mathbb{I P}}$ & $=c_{\mathbf{P}}$ \\
\hline
\end{tabular}

10. Many of the nonspecific components in the analytical results are now known, but some are still unknown. The sum of the major and minor components and the structures in which the analyte is embedded is referred to as the matrix (11). Matrix effects can be quite large. Matrix effects must be monitored on an ongoing basis for routine methods. This requires suitable control specimens with a matrix that is as similar as possible to that of the patient specimens.

i1. The more specific the routine method, the smaller the matrix effects.

For reference methods there are, by definition, no matrix effects.

12. If the accuracy of a method is monitored with method-dependent assigned values this "accuracy" is a relative measure. The comparability of results obtained with different methods is markedly limited by this fact. This is true also for the exchange of information in patient care and in teaching and research. 
13. In the future, accuracy control should therefore take place, whenever possible, by comparing analytical results with reference method values. This yields a reliable control of accuracy.

14. Reference method values obtained from accuracy control specimens with a natural matrix may not be used to calibrate routine methods. The readings obtained with routine methods can be greatly affected by undefined nonspecific components. This markedly reduces the reliability of the measurements.

15. Therefore pure, carefully defined calibration materials without nonspecific components are required for calibration of routine methods.

Calibration materials and control materials must meet very different requirements (16).
Interference factors include all factors that alter the result in vitro, i.e. after the sample has been collected from the patient. They can be divided into two groups:

1. Interference factors that change, the concentration of the parameter to be measured in vitro (e.g. potassium elevation caused by haemolysis as a result of false specimen collection technique).

\section{Interference factors that are different from the parameter to be measured (e.g. interference by haemoglobin in bilirubin determination, interference by drugs in the analysis ).}

They can be eliminated by improving the analytical procedure, especially the specificity.

Tab. 7. Steps in clinical laboratory investigations.

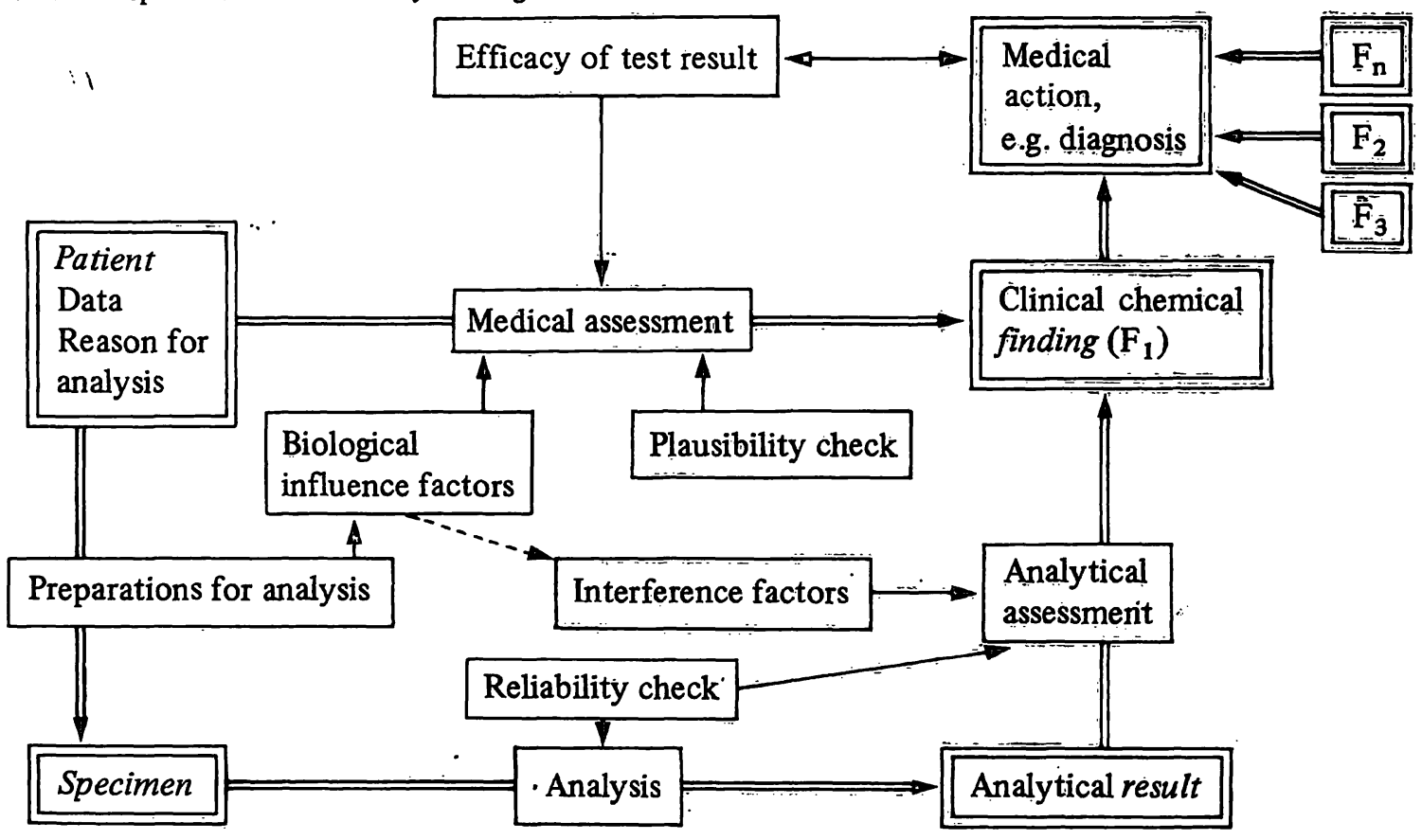

16. The allowable deviation from the reference method values depends on the reason for performing a particular investigation. In order to be able to specify the tolerance limits the effects of the deviation on the other steps in the clinical laboratory investigation (tab. 7), especially medical assessment, mușt be taken into consideration.

17. The diagram showing the steps in clinical laboratory investigations also includes biological influence factors and interference factors $(17,18)$ that can affect the analytical result. These factors must be taken into consideration in assessing results.

Biological influence factors lead to changes in vivo in the clinical chemical parameter. They always have the patient as their point of reference. Their influence is independent of the specificity of the analytical method.
18. It is nöt sufficient to determine only a "total error" $(19,20)$. Instead, one should specify an upper limit for the random error and an upper limit for the systematic error. Only then is it possible to estimate the effect of these errors on medical assessment. If the limits are given for the total error only, then two extreme cases are possible.

1. Method without systematic error but with unnecessarily poor precision.

2. Method with large systematic error that is due to a lack of specificity of the method and therefore can be very dependent on the variable matrix of the specimens.

In the first case one obtains correct results on the average. But in individual cases, due to the effect of precision on the width of the reference interval $(9,21)$, one 
obtains more false positive and false negative findings than necessary.

In the second case a separate reference sample group must be evaluated with this method. Otherwise too many false positive or false negative findings are obtained at the decision limit.

Therefore, in deciding on the maximum allowable deviation from the reference method value for a given constituent, the effects of the random and systematic components must be estimated.

19. This means that for internal quality control there should be separate precision control (Shewhart control chart) and accuracy control, as is currently required in the basic program in the Federal Republic of Germany.

20. Up to now the allowable levels of imprecision in internal quality control according to the basic program have been basad on that which is technically possible $(13,14)$. For some constituents the upper limits have been larger than would be desirable from a clinical standpoint.

In external quality control in the form of interlaboratory surveys the decision limits have been set on the basis of the location and distribution of the analytical results from the particularly high-quality laboratories serving as reference läboratories (15).

21. In the new concept for quality control of clinical laboratory investigations, accuracy should be assessed by a comparison with reference method values. The maximum allowable deviations should be fixed after consideration of their effect on medical assessment of the analytical results.

22. In medical assessment two methods of assessment (9) are in common use.

1. Longitudinal assessment. This is the comparrison of a result from a given patient with eàrlièr results from the șame pâtiènt.

2. Transverse assessment. This is the comparison of a resựlt with the reference interval for a representative reference population.

23. In the longitudinal assessment of two analytical results the critical difference (22), which is referred to as "repeatability" in the ISO Draft International Standard 5725, can be used (tab. 8). Its value is dependent upon the day-to-day standard deviation of the individual values. The critical difference is based on the following considerations. If two random variables are independent and have the same expected value and the same standard deviation $\sigma$, the standard deviation of their difference is $\sqrt{2} \sigma$. Therefore, for Gaussian distributed or approximately Gaussian distributed random variables, the probability that the absolute value of the difference is less than or equal to $2 \sqrt{2} \sigma$ is about 95 percent.

The day-to-day standard deviation from internal precision control $(\mathrm{n}>30)$ can be used for $\sigma$.

Tab. 8. Critical difference.

$d=x_{1}-x_{2}$

where $x_{1}$ and $x_{2}$ are analytical results from single determinations

$\mathrm{p}(|\mathrm{D}|<2 \cdot \sqrt{2} \cdot \sigma) \approx 0.95$

where $D=$ difference between two random variables

$\mathrm{d}_{\mathrm{k}}=2 \cdot \sqrt{2} \cdot \mathrm{s}_{\mathrm{T}} \approx 2.82 \cdot \mathrm{s}_{\mathrm{T}}$

where $d_{k}=$ critical difference

$\mathrm{s}_{\mathrm{T}}=$ standard deviation from day to day

Example: determination of serum chloride

$x_{1}=100 \mathrm{mmol} / \mathrm{l}, \quad x_{2}=108 \mathrm{mmol} / \mathrm{l}, \quad \mathrm{s}_{\mathrm{T}}=2 \mathrm{mmol} / \mathrm{l}$,

$d_{k}=2.82 \cdot 2=5.64, \quad|d|=|100-108|=8>5.64$

If the absolute value of the difference between two analytical results from single determinations is greater than the critical difference, then from an analytical point of view the results can be regarded as being different.

24. Transverse assessment is used in three different situations.

1. Comparison with a reference interval $(23,24)$, e.g. serum potassium;

2. Comparison with a decision limit;

3. Comparison with a therapeutic range.

25. Comparison with a reference interval

The total variance of the reference values $\left(s_{\mathrm{RV}}\right)$ of a reference sample group is dependent on a number of components (tab. 9).

The width of the reference interval depends on the same components.

Tab. 9. Variation of the reference values (reference population).

\begin{tabular}{ll}
\hline Variation & Numerical value \\
\hline Intraindividual - & $s_{\mathrm{B} \text { intra }}$ \\
Interindividual - & $s_{\mathrm{B} \text { inter }}$ \\
Biological - & $s_{\mathrm{B}}=\sqrt{\mathrm{s}_{\mathrm{B} \text { intra }}^{2}+s_{\mathrm{B} \text { inter }}^{2}}$ \\
Total - & $s_{\mathrm{B}}=\sqrt{\mathrm{s}_{\mathrm{B}}^{2}+\mathrm{s}_{\mathrm{AD}}^{2}+s_{\mathrm{O}}^{2}}$ \\
Other - & $s_{\mathrm{O}}$ \\
\hline
\end{tabular}

$s_{B}=$ biological variation

$s_{A D}=$ analytical between-day imprecision 
The biological variation is quite different for different constituents. For highly precise homeostatic regulation such as S-sodium, S-calcium and $\mathrm{S}$ chloride $^{1}$ ) it can be less than $2 \%$, for intermediate degrees of regulation such as S-potassium, S-glucose, S-cholesterol and S-phosphate ${ }^{1}$ ) it can be $5 \%$ to $10 \%$, and for end products of metabolism such as urea and uric acid and cell enzymes in serum such as aspartate aminotransferase it can be as high as $25 \%$.

In each case different requirements must be made regarding the level of day-to-day precision needed because of the effects on medical assessment (25, $9,26)$.

The most rigid requirements:

$$
\frac{s_{B}}{s_{A D}} \geqq 2
$$

If the biological variation is unknown:

$$
\frac{\text { reference interval }}{\mathrm{S}_{\mathrm{AD}}{ }^{\prime}} \geqq 8
$$

\section{Comparison with a decision limit}

In a comparison with a decision limit, as is the case for the oral glucose tolerance test, quotients should be calculated as shown in statement 25 ; for an example of the distribution of values at the decision limit see figure 1 (27).

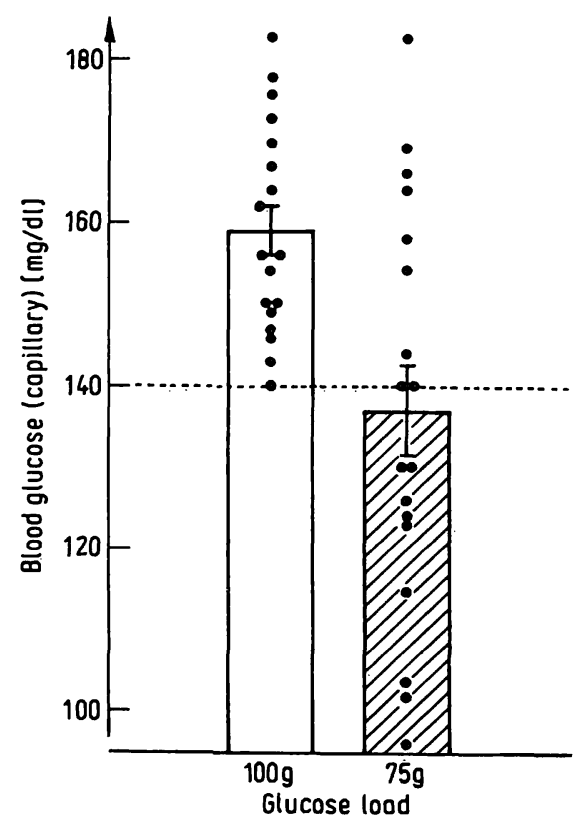

Fig. 1. Blood glucose concentration of 18 patients with subclinical diabetes (disturbed glucose tolerance) 120 minutes after oral administration of $75 \mathrm{~g}$ and $100 \mathrm{~g}$ of glucose $(\bar{x}+$ S.E.M. $)$.

Modified from Bachmann, published in l.c. (20).
27. The procedure with transverse assessment by means of a comparison with the therapeutic range is still to be discussed and agreed upon.

28. For internal accuracy control the maximum allowable deviation from the reference method value should not be greater than plus or minus twice (28.1) or, as an alternative, plus or minus three times (28.2) the maximum allowable standard deviation from day to day.

29. The decision limits for interlaboratory surveys should be fixed in the same manner as the maximum allowable deviations for internal quality control (29.1) or, as an alternative, they should be $1 \frac{1}{2}$ times the allowable deviation in internal accuracy control (29.2).

It appears to be absolutely essential, however, to check every control specimen to be used in an interlaboratory survey to see whether the results from three reference laboratories obtained with the best available routine methods are actually within these limits. This evaluation should take the form of a long-term interlaboratory survey, for example such as we carry out for assigned value determination (15).

At the same time this would provide documentation to the participants in interlaboratory surveys of the suitability of a given control specimen.

\section{Effects on medical action}

The introduction of accuracy control via a comparison with the reference method value and the use of decision limits that are derived from clinical requirements would bring the clinical laboratory analysis a large step closer to the goal of correct analytical results. This would induce users to give preference again to the more reliable and especially more specific methods.

Analytical results and findings obtained with different methods in different laboratories could then be compared with each other with a level of reliability adequate for clinical purposes. In addition, the determination of method-dependent reference values and the reference intervals based on them might become unnecessary.

The large number of interfèrence factors in nonspecific methods that have to be considered in the medical assessment would definitely not increa and would probably actually decrease."

All of these advantages of a quality control system involving reference method values would justify the cost of such a program because of the increase in the reliability of the findings. 
This paper was prepared at the request of the Commission on Standardization of the German Society for Clinical Chemistry and presented and discussed in Munich on April 27, 1982 at the Joint Meeting of the
Commissions on Standardization of the European Countries on the occasion of Biochemische Analytik. Comments and suggestions would be welcomed and should be sent directly to the author.

\section{References}

Since it is impossible to print a complete list of references here, this list includes only the Recommendations of the IFCC and a few recent overviews and original papers with extensive reference lists.

1. Büttner, J., Borth, R., Boutwell, J. H., Broughton, P. M. G. \& Bowyer, R. C. (1979)

Approved Recommendation (1978) on Quality Control in Clinical Chemistry. Part 1. General principles and terminology.

Clin. Chim. Acta 98, 129F-143F; reprinted in J. Clin. Chem. Clin. Biochem. 18, 69-77 (1980).

2. Büttner, J., Borth, R., Boutwell, J. H., Broughton, P. M. G. \& Bowyer, R. C. (1979)

Approved Recommendation (1978) on Quality Control in Clinical Chemistry. Part 2. Assessment of analytical methods for routine use.

Clin. Chim. Acta 98, 145F-162F; reprinted in J. Clin. Chem. Clin. Biochem. 18, 78-88 (1980).

3. Büttner, J., Borth, R., Boutwell, J. H., Broughton, P. M. G. \& Bowyer, R. C. (1980)

Approved Recommendation (1979) on Quality Control in Clinical Chemistry. Part 3. Calibration and control materials. J. Clin. Chem. Clin. Biochem. 18, 855-860; Clin. Chim. Acta 109, F105-F114 (1981).

4. Büttner, J., Borth, R., Broughton, P. M. G. \& Bowyer, R. C. (1980)

Recommendation on Quality Control in Clinical Chemistry. Part. 4. Internal quality control.

Clin. Chim. Acta 83, 189F-202F; reprinted in J. Clin. Chem. Clin. Biochem. 18, 535-541.

5. Büttner, J., Borth, R., Boutwell, J. H., Broughton, P. M. G. \& Bowyer, R. C. (1978)

Provisional Recommendation on Quality Control in Clinical Chemistry. Part 5. External quality control.

Clin. Chim. Acta 83, 189F-202 F; reprinted in J. Clin. Chem. Clin. Biochem. 16, 259-266 (1978) and Clin. Chem. 24, $1213-1220$ (1978).

6. Büttner, J., Borth, R., Boutwell, J. H., Broughton, P. M. G. \& Bowyer, R.C. (1980)

Approved Recommendation (1979) on Quality Control in Clinical Chemistry. Part 6. Quality requirements from the point of view of health care.

J. Clin. Chem. Clin. Biochem. 18, 861-866; Clin. Chim. Acta 109, F115-F124 (1981)

7. Symposium Quality Control, Experiences and New Aspects, Moderator: D. Stamm.

With contributions by M. Hjelm (Cälibration materials and control materials), D. D. Bayse (Reference methods),

D. Stamm (Models for statistical quality control), and H. U. Bergmeyer (Industrial resëarch and development). In: XI International Congress of Clinical Chemistry Proceedings, Vienna, Austria, Auguist 30-September 5, 1981 (Müller, M. M., Kaiser, E., Gabl, F. \& Bäyer, P. M., eds.) Walter de Gruyiter, Berlin, New York, pp. 1487-1549 (1982).

8. Boutwèll, J. H. (ed.) (1978)

A National Understanding for the Development of Reference Materials and Methods for Clinical Chemistry. Pro=ceedings of a Conference.

American Association for Clinical Chemistry, Washington, D.C.

9. Büttner, H., Hansert, E. \& Stamm, D. (1974)

Statistical analysis, control and assessment of experimental results.
In: Methods of Enzymatic Analysis (Bergmeyer, H. U., ed.), Second English edition, translated from the third German edition, Vol. 1, pp. 318-395.

Verlag Chemie, Weinheim; Academic Press Inc., New York, London.

10. Kaiser, H. (1965)

Zum Problem der Nachweisgrenze.

Z. Anal. Chem. 209, 1.

11. Stamm, D. (1979)

Reference materials and reference methods in clinical chemistry.

J. Clin. Chem. Clin. Biochem. 17, 283-297.

12. Stamm, D. (1979)

Recommendations for the description of a selected method in clinical chemistry.

J. Clin. Chem. Clin. Biochem. 17, 280-282.

13. Guidelines of the Medical Society of West Germany for statistical quality control and collaborative surveys. Mitteilungen der Deutschen Gesellschaft für Klinische Chemie 3, 33-36 (1974).

Originally published in German in Deutsches Ärzteblatt 68 , 2228-2231 (1971).

14. Regulations and explanations regarding the implementation of the guidelines of the Medical Society of West Germany. Mitteilungen der Deutschen Gesellschaft für Klinische Chemie 3, 36-42 (1974).

Originally published in German in Deutsches Ärzteblatt 71, 959-965 (1974).

15. Hansert, E. \& Stamm, D. (1980)

Determination of assigned values in control specimens for internal accuracy control and for interlaboratory surveysEvaluation of 200 different lots with identical experimental design: Experiences and conclusions. .

J. Clin. Chem. Clin. Biochem. 18, 461-490.

16. Stamm, D. (1974)

Calibration and quality control materials.

Z. Klin. Chem. Klin. Biochem. 12, 137-145.

17. Guder, W. G. (1980)

Einflußgrößen und Störfaktoren bei klinisch-chemischen Untersuchungen.

Internist 21, 533--542.

18. Young, D. S., Pestaner, L. C. \& Gibberman, V. (1975) Effects of drugs on clinical laboratory tests. Clin. Chem. 21, 1D-432D.

19. Westgard, J. O. (1977)

The development of performance standards and criteria for testing the precision and accuracy of laboratory methods. In: l.c. (20), pp. 105-113.

20. Elevitch, F. R. (ed.) (1977) Proceedings of the 1976. Aspen Conference on Analytical Goals in Clinical Chemistry. College of American Pathologists, Chicago.

21. Gowenlock, A. H. \& Broughton, P. M. G. (1968) The influence of accuracy and precision on the normal range and on acceptable limits for an analy tical result. Z. Analyt. Chem. 243, 774-780.

22. Stamm, D. (1981) Control of analytical variation in the production of reference values.

In: l.c. (23), pp. 109-126.

23. Gräsbeck, R. \& Alström, T. (eds.) (1981) Reference Values in Laboratory Medicine. John Wiley \& Sons Ltd., Chichester, New York, Brisbane, Toronto, Singapore. 
24. Gräsbeck, R., Siest, G., Wilding, P., Williams, G. Z. \& Whitehead, T. P. (1978)

Provisional Recommendations on the Theory of Reference Values (1978) Part 1. The concept of reference values.

Clin. Chim. Acta 87, F459-F65; reprinted in J. Clin. Chem. Clin. Biochem. 17, 337-339 (1979) and Clin. Chem. 25, 1506-1508 (1979).

25. Büttner, H. (1973)

Präzisierung von Normalbereichen.

In: Optimierung der Diagnostik (Lang, H., Rick, W. \& Róka, L., eds.) pp. 233-241.

Springer-Verlag Berlin, Heidelberg, New York.
26. Cotlove, E., Harris, E. K. \& Williams, G. Z. (1970) Biological and analytical components of variation in long-term studies of serum constituents in normal subjects. III. Physiological and medical implications.

Clin. Chem. 16, 1028-1032.

27. Haslbeck, M. (1981) Diagnostische Probleme bei Diabetes mellitus.
Internist $22,18 \overline{7}=196$.

Please send comments and suggestions to:

Professor Dr. Dr. Dankwart Stamm

Leiter der Abteilung für Klinische Chemie

Max-Planck-Institut für Psychiatrie

Kraepelinstrạße 10

D-8000 München 40

Federal Republic of Germany 